\title{
Fish trypanosomes from the Okavango Delta, Botswana
}

\author{
Nico J. Smit ${ }^{1,2}$, Jo G. Van As $^{3}$ and Angela J. Davies ${ }^{1}$ \\ ${ }^{1}$ School of Life Sciences, Faculty of Science, Kingston University, Penrhyn Road, Kingston upon Thames, Surrey, KT1 2EE, \\ $\mathrm{UK}$; \\ ${ }^{2}$ Department of Zoology, Rand Afrikaans University, P.O. Box 524, Auckland Park, 2006, South Africa; \\ ${ }^{3}$ Department of Zoology and Entomology, University of the Free State, P.O. Box 339, Bloemfontein, 9300, South Africa
}

Key words: Trypanosoma, fish parasites, Botswana

\begin{abstract}
During 2001 and 2002, blood smears from 37 of 120 fishes belonging to 10 species captured in the Okavango Delta region of Botswana, were found to harbour trypanosomes. These trypanosomes displayed differing staining properties, were morphometrically variable, and ranged in total length from 29.5 to $80.8 \mu \mathrm{m}$. Mixed populations of the smaller and larger trypanosomes were found in most fish examined. Despite variations in size and appearance, these specimens are tentatively identified as Trypanosoma mukasai Hoare, 1932, likely adding another 9 new hosts to those known for this parasite. It is possible that Trypanosoma clariense Pienaar, 1962, described from Clarias gariepinus in South Africa, is also a junior synonym of $T$. mukasai.
\end{abstract}

Prior to 1960, knowledge of trypanosomes infecting freshwater fishes in Africa was limited to probably 13 publications describing almost as many species (see Baker 1960, 1961). These records were from fishes in French West Africa, the Congo, the Sudan, Uganda, Mozambique and Natal (Baker 1960, 1961). Careful scrutiny of these reports led Baker (Baker 1960, 1961) to conclude that only three of these species could be considered valid: Trypanosoma toddi Bouet, 1909, Trypanosoma mukasai Hoare, 1932 and Trypanosoma tobeyi Dias, 1952. Even so, Baker (1960) noted that a "small difference in nuclear position" was the only character separating $T$. toddi from $T$. tobeyi. He also reported that $T$. toddi was not remarkably different from T. mukasai and T. tobeyi might prove a synonym of the same trypanosome. Since 1961, new species of trypanosomes from freshwater fishes have been described from South Africa and Egypt (see Pienaar 1962, Negm-Eldin 1997, 1998), and Trypanosoma froesi Lima, 1976 from the rivers and lagoons of southern Africa (see Paperna 1996, Smit et al. 2000). However, elucidation of the life cycle of T. mukasai, involving its transmission to a variety of wild-caught host fishes, has led to the conclusion (Negm-Eldin 1998) that most records of freshwater fish trypanosomes across Africa may be of a single species (T. mukasai).

Recently, a single fish trypanosome from the silver catfish Schilbe intermedius Rüppell, 1832, tentatively identified as T. mukasai, was discovered in the Okavango Delta region of Botswana (Smit et al. 2000). During 2000 and 2001, blood from further fishes was obtained from this source, and the results are reported here.

\section{MATERIALS AND METHODS}

Fish were collected in the panhandle region of the Okavango Delta using hand, seine, cast, and gills nets, or by rod and line (see Reed et al. 2002) in June and July of 2001, and during August of 2002. In a mobile field laboratory, fish were measured, identified (Skelton 2000), and kept in aerated aquaria containing fresh river water. Heart blood smears were fixed in absolute methanol, stained with phosphate-buffered Giemsa (pH 6.8) and screened for blood parasites with a $100 \times$ objective on a Zeiss Axioskop 20 photomicroscope. Microscopic images were captured by digital camera (Nikon DN100), stored on computer disks and then parasites were measured with an Eclipse Net (Nikon) image analysis package, calibrated to a stage micrometer.

\section{RESULTS}

The identity, numbers and lengths of fishes captured, and parasite prevalence are recorded in Table 1. Thirtyseven of 120 fishes, in five families, six genera and ten species, were infected with trypanosomes (Table 1) and infections were generally light. One fish, a thinface largemouth tilapia, Serranochromis angusticeps, was parasitized by both a trypanosome and a dactylosomatid that is described elsewhere (Smit et al. 2003). No fish was found to bear haematophagous ectoparasites that might act as vectors of these infections.

Trypanosomes varied considerably in size (Table 2) and staining properties, and small and large trypanosomes formed mixed populations in most smears examined (Figs. 1-12). The smallest trypanosomes (in overall length) were found in the nembwe, Serranochromis robustus, and the largest in the Zambezi grunter, Parauchenoglanis ngamensis (Fig. 9), but there was overlap between sizes of trypanosomes among the 
Table 1. Identity, number and length of fishes captured in the Okavango Delta and prevalence of blood parasites in these fishes. Abbreviations: $\mathrm{n}$ - number; $\mathrm{ML}$ - mean length; $\mathrm{SD}$ - standard deviation.

\begin{tabular}{|c|c|c|c|}
\hline \multicolumn{3}{|l|}{ Fishes } & \multirow{2}{*}{$\begin{array}{c}\text { Trypanosomes } \\
\text { Prevalence }(\%)\end{array}$} \\
\hline Species & $\mathrm{n}$ & $\mathrm{ML} \pm \mathrm{SD}$ (range) in $\mathrm{mm}$ & \\
\hline $\begin{array}{l}\text { A } \mathrm{n} \text { a b a } \mathrm{nt} \mathrm{i} \mathrm{d} \text { a e } \\
\text { Ctenopoma multispine Peters, } 1844\end{array}$ & 1 & 73 & $0 / 1(0)$ \\
\hline Cichlidae & & & \\
\hline Oreochromis andersonii (Castelnau, 1861) & 6 & $308.2 \pm 88.6(135-360)$ & $1 / 6(17)$ \\
\hline Sargochromis codringtonii (Boulenger, 1908) & 1 & 256 & $0 / 1(0)$ \\
\hline Serranochromis angusticeps (Boulenger, 1907) & 4 & $299.3 \pm 25.9(280-312)$ & $2 / 4(50)$ \\
\hline Serranochromis macrocephalus (Boulenger, 1899) & 4 & $267.3 \pm 31.2(232-294)$ & $2 / 4(50)$ \\
\hline Serranochromis robustus (Günther, 1864) & 8 & $341.6 \pm 25.9(305-380)$ & $4 / 8(50)$ \\
\hline Tilapia rendalli (Boulenger, 1897) & 1 & 293 & $0 / 1(0)$ \\
\hline Tilapia sparrmanii Smith, 1840 & 1 & 140 & $0 / 1(0)$ \\
\hline Characidae & & & \\
\hline Brycinus lateralis (Boulenger, 1900) & 1 & 103 & $0 / 1(0)$ \\
\hline Rhabdalestes maunensis (Fowler, 1935) & 1 & 43 & $0 / 1(0)$ \\
\hline Micralestes acutidens (Peters, 1852) & 1 & 71 & $0 / 1(0)$ \\
\hline Hydrocynus vittatus Castelnau, 1861 & 6 & $485.3 \pm 188.9(205-680)$ & $0 / 6(0)$ \\
\hline Clariidae & & & \\
\hline Clarias gariepinus (Burchell, 1822) & 7 & $686.4 \pm 132.1(455-840)$ & $3 / 7(43)$ \\
\hline Clarias stappersii Boulenger, 1915 & 6 & $191.8 \pm 221.5(42-485)$ & $0 / 6(0)$ \\
\hline Clarias theodorae Weber, 1897 & 8 & $201.6 \pm 37.2(114-237)$ & $8 / 8(100)$ \\
\hline $\begin{array}{l}\text { C } 1 \text { a r o t e i d a e } \\
\text { Parauchenoglanis ngamensis (Boulenger, 1911) }\end{array}$ & 1 & 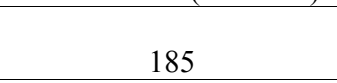 & $1 / 1(100)$ \\
\hline $\begin{array}{l}\text { C y } \mathrm{p} \text { r in i d a e } \\
\text { Barbus miolepis } \text { Boulenger, } 1902 \\
\text { Barbus paludinosus } \text { Peters, } 1852\end{array}$ & $\begin{array}{l}1 \\
1\end{array}$ & $\begin{array}{c}75 \\
110\end{array}$ & $\begin{array}{l}0 / 1(0) \\
0 / 1(0)\end{array}$ \\
\hline $\begin{array}{l}\text { He p s e t i d a e } \\
\text { Hepsetus odoe (Bloch, 1794) }\end{array}$ & 13 & $339.2 \pm 34.7(284-395)$ & $0 / 13(0)$ \\
\hline $\begin{array}{l}\text { M o c h o k i d a e } \\
\text { Synodontis nigromaculatus Boulenger, } 1905 \\
\text { Synodontis macrostoma Boulenger, } 1911 \\
\text { Synodontis vanderwaali Skelton et White, } 1990\end{array}$ & $\begin{array}{c}14 \\
1 \\
4\end{array}$ & $\begin{array}{c}214.8 \pm 32.1(162-260) \\
155 \\
206.25 \pm 7.5\end{array}$ & $\begin{array}{c}11 / 14(79) \\
0 / 1(0) \\
3 / 4(75) \\
\end{array}$ \\
\hline $\begin{array}{l}\text { M o r m y r i d a e } \\
\text { Marcusenius lacerda Castelnau, } 1861 \\
\text { Marcusenius macrolepidotus (Peters, 1852) } \\
\text { Petrocephalus catostoma (Günther, 1866) }\end{array}$ & $\begin{array}{l}1 \\
2 \\
1\end{array}$ & $\begin{array}{l}375 \\
200 \text { and } 210 \\
50\end{array}$ & $\begin{array}{l}0 / 1(0) \\
0 / 2(0) \\
0 / 1(0)\end{array}$ \\
\hline $\begin{array}{l}\text { S c h i } 1 \text { b e i d a e } \\
\text { Schilbe intermedius Rüppell, } 1832\end{array}$ & 25 & $235.9 \pm 54.8(120-307)$ & $2 / 25(8)$ \\
\hline Tot a 1 & 120 & & $37 / 120(31)$ \\
\hline
\end{tabular}

different species of fishes (see Table 2). Generally, the smaller trypanosomes were pale-stained with Giemsa, whereas the larger ones stained deeply, sometimes showing longitudinal striations (Fig. 9). The most delicately stained trypanosomes were found among the Clarias spp. (Fig. 5), but the small trypanosomes found in other fishes such as the finetooth squeaker Synodontis vanderwaali (Fig. 11) and Schilbe intermedius (Fig. 12) were indistinguishable from those found in Clarias spp.

Nuclei in the small trypanosomes were often oval and longer than wide, whereas those in the larger trypanosomes also tended to be oval, but wider than long (Figs. 1-12). Free flagella were generally rather short and not easily stained, especially in the larger trypanosomes. The undulating membrane was well developed and a distinct kinetoplast lay near the posterior end of the body (Figs. 1-12). Comparison of flagellar indices (FI values) (see Becker and Overstreet 1979) were unhelpful in distinguishing between trypanosome types, but nuclear indices (NI values) (see Becker and Overstreet 1979) were consistently $>1$, indicating that the nucleus lay forward of the mid-point of the body for the majority of trypanosomes measured.

\section{DISCUSSION}

In the current Okavango Delta study, the large number of fishes infected with trypanosomes and the variety of these flagellates were surprising, especially given the paucity of these in the previous study at the same time of year (Smit et al. 2000). The small trypanosomes seen in several fishes, especially Parauchenoglanis ngamensis and the threespot tilapia Oreochromis andersonii, closely resembled Trypanosoma mukasai in 
Table 2. Morphometrics of the trypanosomes collected in the Okavango Delta. Abbreviations: SD - standard deviation; $\mathrm{n}$ - number trypanosomes measured; MA - midnucleus to anterior; MP - midnucleus to posterior; MK - midnucleus to kinetoplast; PK - posterior to kinetoplast; NL - nucleus length; BW - body width; TBL - total body length; OL - overall length including free flagellum; NI - nuclear index; FI - flagellar index.

\begin{tabular}{|c|c|c|c|c|c|c|c|c|c|c|c|}
\hline \multirow{2}{*}{ Fish host } & \multicolumn{11}{|c|}{ Trypanosome morphometrics: Mean \pm SD (range) } \\
\hline & $\mathrm{n}$ & MA & MP & MK & PK & NL & BW & TBL & OL & $\mathrm{NI}$ & FI \\
\hline Oreochromis andersonii & 5 & $\begin{array}{c}22.2 \pm 4.3 \\
(17.3-27.3)\end{array}$ & $\begin{array}{c}23.9 \pm 3.7 \\
(19.3-28.2)\end{array}$ & $\begin{array}{c}22.5 \pm 3.5 \\
(17.9-26.4)\end{array}$ & $\begin{array}{l}1.4 \pm 0.3 \\
(1.1-1.8)\end{array}$ & $\begin{array}{l}3.4 \pm 0.3 \\
(2.9-3.7)\end{array}$ & $\begin{array}{l}4.6 \pm 1.0 \\
(3.9-5.6)\end{array}$ & $\begin{array}{c}46.1 \pm 7.9 \\
(37.7-53.6)\end{array}$ & $\begin{array}{c}54.6 \pm 8.8 \\
(45.2-63.3)\end{array}$ & 1.1 & 5.4 \\
\hline Serranochromis angusticeps & 10 & $\begin{array}{c}20.9 \pm 2.3 \\
(17.3-24.8)\end{array}$ & $\begin{array}{c}25.4 \pm 1.9 \\
(23.6-29.1)\end{array}$ & $\begin{array}{c}23.1 \pm 2.1 \\
(19.4-26.8)\end{array}$ & $\begin{array}{l}2.3 \pm 0.5 \\
(1.6-2.9)\end{array}$ & $\begin{array}{l}4.1 \pm 0.4 \\
(3.6-4.6)\end{array}$ & $\begin{array}{l}4.8 \pm 1.1 \\
(3.2-6.2)\end{array}$ & $\begin{array}{c}46.3 \pm 1.4 \\
(43.9-48.2)\end{array}$ & $\begin{array}{c}55.0 \pm 1.4 \\
(51.6-57.1)\end{array}$ & 1.2 & 5.3 \\
\hline Serranochromis macrocephalus & 4 & $\begin{array}{c}22.2 \pm 2.1 \\
(19.1-23.6)\end{array}$ & $\begin{array}{c}26.5 \pm 0.7 \\
(25.5-27.2)\end{array}$ & $\begin{array}{c}23.7 \pm 1.0 \\
(22.3-24.7)\end{array}$ & $\begin{array}{l}2.8 \pm 0.3 \\
(2.5-3.2)\end{array}$ & $\begin{array}{l}4.4 \pm 0.5 \\
(3.9-5.0)\end{array}$ & $\begin{array}{l}4.9 \pm 1.0 \\
(3.9-6.1)\end{array}$ & $\begin{array}{c}48.6 \pm 2.8 \\
(44.6-50.8)\end{array}$ & $\begin{array}{c}56.8 \pm 4.2 \\
(51.5-61.6)\end{array}$ & 1.2 & 5.9 \\
\hline Serranochromis robustus & 20 & $\begin{array}{l}19.3 \pm 5.1 \\
(8.2-27.3) \\
\end{array}$ & $\begin{array}{c}23.2 \pm 4.2 \\
(15.5-33.6)\end{array}$ & $\begin{array}{c}21.5 \pm 3.9 \\
(14.5-31.5)\end{array}$ & $\begin{array}{l}1.7 \pm 0.4 \\
(0.9-2.2) \\
\end{array}$ & $\begin{array}{l}3.7 \pm 0.8 \\
(2.6-5.8) \\
\end{array}$ & $\begin{array}{l}3.7 \pm 1.2 \\
(1.4-5.7) \\
\end{array}$ & $\begin{array}{c}42.5 \pm 8.9 \\
(23.6-60.9)\end{array}$ & $\begin{array}{c}50.2 \pm 9.6 \\
(29.5-70.1)\end{array}$ & 1.2 & 5.5 \\
\hline Clarias gariepinus & 25 & $\begin{array}{l}15.6 \pm 3.2 \\
(8.6-22.1) \\
\end{array}$ & $\begin{array}{c}17.8 \pm 2.3 \\
(13.1-22.2) \\
\end{array}$ & $\begin{array}{c}16.5 \pm 2.1 \\
(12.2-20.5) \\
\end{array}$ & $\begin{array}{l}1.3 \pm 0.2 \\
(0.8-1.7)\end{array}$ & $\begin{array}{l}3.4 \pm 0.5 \\
(1.9-4.1)\end{array}$ & $\begin{array}{l}2.4 \pm 0.5 \\
(1.2-3.6)\end{array}$ & $\begin{array}{c}33.3 \pm 5.0 \\
(21.7-41.5) \\
\end{array}$ & $\begin{array}{c}43.8 \pm 5.4 \\
(30.1-52.4) \\
\end{array}$ & 1.2 & 3.2 \\
\hline Clarias theodorae & 25 & $\begin{array}{c}21.7 \pm 3.9 \\
(10.9-26.9) \\
\end{array}$ & $\begin{array}{c}24.4 \pm 4.8 \\
(11.8-30.4)\end{array}$ & $\begin{array}{c}22.7 \pm 4.7 \\
(10.5-28.4) \\
\end{array}$ & $\begin{array}{l}1.7 \pm 0.2 \\
(1.4-2.1)\end{array}$ & $\begin{array}{l}4.3 \pm 0.8 \\
(3.2-5.5)\end{array}$ & $\begin{array}{l}2.4 \pm 0.4 \\
(1.8-3.5)\end{array}$ & $\begin{array}{c}46.2 \pm 8.2 \\
(22.7-54.9)\end{array}$ & $\begin{array}{c}54.0 \pm 7.8 \\
(32.7-62.5)\end{array}$ & 1.1 & 5.9 \\
\hline Parauchenoglanis ngamensis & 25 & $\begin{array}{c}23.6 \pm 9.1 \\
(11.0-40.0)\end{array}$ & $\begin{array}{c}27.7 \pm 7.4 \\
(15.0-40.0)\end{array}$ & $\begin{array}{c}24.9 \pm 6.5 \\
(13.4-33.8)\end{array}$ & $\begin{array}{l}2.7 \pm 1.4 \\
(1.5-6.2)\end{array}$ & $\begin{array}{l}4.0 \pm 0.6 \\
(3.2-5.0)\end{array}$ & $\begin{array}{c}5.6 \pm 2.2 \\
(2.3-11.5)\end{array}$ & $\begin{array}{l}51.3 \pm 16.2 \\
(30.8-75.4)\end{array}$ & $\begin{array}{l}59.1 \pm 16.6 \\
(33.1-80.8)\end{array}$ & 1.2 & 6.5 \\
\hline Synodontis nigromaculatus & 20 & $\begin{array}{c}16.6 \pm 3.2 \\
(10.3-20.2)\end{array}$ & $\begin{array}{c}22.6 \pm 2.9 \\
(17.7-27.3)\end{array}$ & $\begin{array}{c}21.0 \pm 3.1 \\
16.2-25.8) \\
\end{array}$ & $\begin{array}{l}1.6 \pm 0.3 \\
(1.1-2.2)\end{array}$ & $\begin{array}{l}3.7 \pm 0.5 \\
(2.7-4.6)\end{array}$ & $\begin{array}{l}3.2 \pm 0.7 \\
(2.0-4.0)\end{array}$ & $\begin{array}{c}39.2 \pm 4.5 \\
(28.0-43.6)\end{array}$ & $\begin{array}{c}47.8 \pm 5.0 \\
(36.6-54.0)\end{array}$ & 1.4 & 4.6 \\
\hline Synodontis vanderwaali & 10 & $\begin{array}{l}14.8 \pm 3.0 \\
(10-18.6) \\
\end{array}$ & $\begin{array}{c}19.2 \pm 3.1 \\
(14.6-23.3)\end{array}$ & $\begin{array}{c}18.1 \pm 3.1 \\
(13.6-22.1) \\
\end{array}$ & $\begin{array}{l}1.1 \pm 0.1 \\
(0.9-1.4)\end{array}$ & $\begin{array}{l}3.0 \pm 0.5 \\
(2.2-3.7)\end{array}$ & $\begin{array}{l}2.0 \pm 0.6 \\
(1.1-3.0)\end{array}$ & $\begin{array}{c}34.1 \pm 5.5 \\
(26.7-40.9) \\
\end{array}$ & $\begin{array}{c}40.6 \pm 6.1 \\
(32.0-48.1) \\
\end{array}$ & 1.3 & 5.2 \\
\hline Schilbe intermedius & 10 & $\begin{array}{c}16.0 \pm 2.8 \\
(13.1-19.5)\end{array}$ & $\begin{array}{c}23.0 \pm 3.3 \\
(18.0-26.7)\end{array}$ & $\begin{array}{c}21.4 \pm 3.5 \\
(16.0-25.2)\end{array}$ & $\begin{array}{l}1.5 \pm 0.4 \\
(1.3-2.1)\end{array}$ & $\begin{array}{l}3.7 \pm 0.6 \\
(2.6-4.4)\end{array}$ & $\begin{array}{l}3.8 \pm 0.9 \\
(2.5-4.7)\end{array}$ & $\begin{array}{c}38.3 \pm 4.3 \\
(31.6-42.5)\end{array}$ & $\begin{array}{c}47.0 \pm 5.3 \\
(35.3-51.6)\end{array}$ & 1.4 & 4.4 \\
\hline
\end{tabular}




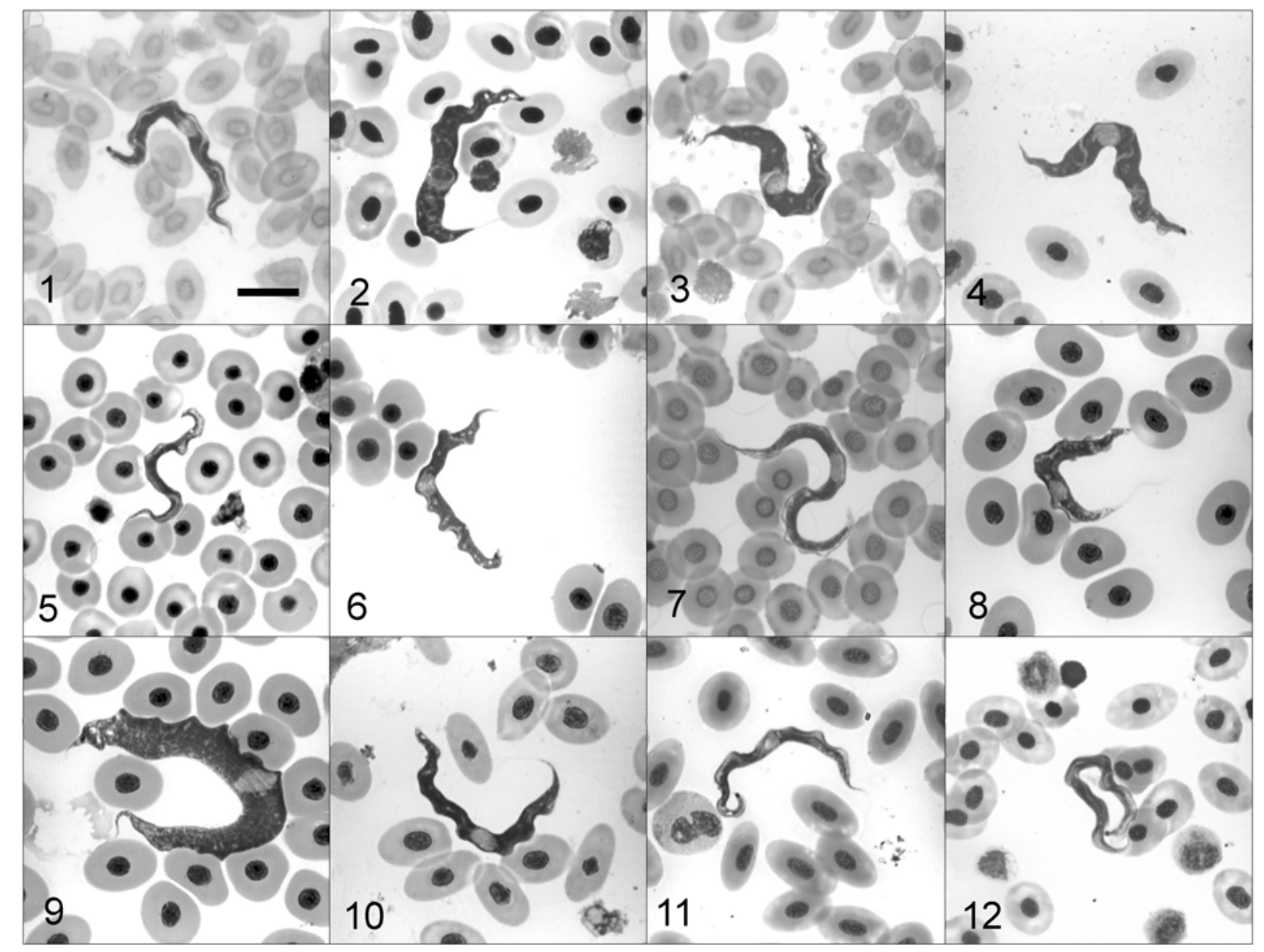

Figs. 1-12. Light micrographs of suspected Trypanosoma mukasai from different fishes in the Okavango Delta. Fig. 1. Oreochromis andersonii. Fig. 2. Serranochromis angusticeps. Fig. 3. Serranochromis macrocephalus. Fig. 4. Serranochromis robustus. Fig. 5. Clarias gariepinus small form. Fig. 6. C. gariepinus larger form. Fig. 7. Clarias theodorae. Fig. 8. Parauchenoglanis ngamensis small form. Fig. 9. P. ngamensis large form. Fig. 10. Synodontis nigromaculatus. Fig. 11. Synodontis vanderwaali. Fig. 12. Schilbe intermedius. Scale bar $=10 \mu \mathrm{m}$ for Figs. 1-12.

size and morphology. Baker (1960) found small examples of this species in Tilapia esculenta, T. variabilis and Bagrus docmac from Lake Victoria. We presume that the small forms found in our samples are immature stages of this same trypanosome, and probably represent a recent infection. The larger trypanosomes found in the Cichlidae and Mochokidae in Botswana were also morphologically similar to and fell within the size ranges for $T$. mukasai. The largest trypanosome, seen in $P$. ngamensis (80.8 $\mu \mathrm{m}$ long), was longer than T. mukasai reported from Uganda (see Baker 1960), but within the record (up to $90 \mu \mathrm{m}$ ) for experimental infections (Negm-Eldin 1998).

Baker (1960) commented that nuclear position, rather than flagellar length may be important in distinguishing the three African freshwater fish trypanosomes that he suspected might be valid species. The nucleus lies forward of the mid-line consistently in the trypanosomes recorded in this study (see NI values), which supports their identity as T. mukasai. However, T. tobeyi, originally named from Clarias angolensis (see Baker 1960), also has an anterior nucleus. The suggestion that $T$. tobeyi might be synonymous with $T$. mukasai (see Baker 1960), and the subsequent transmission of $T$. mukasai from Clarias lazera to a variety of genera of wild-caught freshwater fishes by Negm-Eldin (1998), leads to the conclusion that they probably are the same species.

Trypanosoma froesi (=Trypanosoma mugilicola Becker et Overstreet, 1979) occurs in the Mugilidae, and so the only other truly freshwater trypanosome from southern Africa is Trypanosoma clariense Pienaar, 1962 infecting a single sharptooth catfish Clarias gariepinus caught in the Potchefstroom district in the North West Province of South Africa. Unusually, Pienaar (1962) reported this species in his study of blood parasites of South African reptiles. The total body length (35-48 $\mu \mathrm{m})$ and width $(1.3-2.7 \mu \mathrm{m})$ of this parasite fall within 
the ranges of those from $C$. gariepinus in the Okavango Delta, as well as those of T. mukasai. Pienaar (1962) also mentioned the difficulty in staining the free flagellum, a characteristic found in the majority of the Okavango specimens. Based on Pienaar's (1962) original description (no type material was deposited), the name Trypanosoma clariense may therefore also prove to be a junior synonym of T. mukasai.

Trypanosoma mukasai is thus tentatively recorded from 9 new host fishes in this study: Oreochromis andersonii, Serranochromis angusticeps, S. macrocephalus, $S$. robustus, Clarias gariepinus, C. theodorae,
Parauchenoglanis ngamensis, Synodontis nigromaculatus, and $S$. vanderwaali. While many trypanosomes observed in the Okavango Delta material can almost certainly be attributed to T. mukasai, their varied size, staining properties and host fishes suggest that careful molecular studies would be helpful in confirming whether they are, in fact, identical genetically.

Acknowledgements. We are grateful to the Debswana Diamond Company and Land Rover South Africa for sponsoring this work in the Okavango Delta.

\section{REFERENCES}

BAKER J.R. 1960: Trypanosomes and dactylosomes from the blood of fresh-water fish in East Africa. Parasitology 50: $515-526$.

BAKER J.R. 1961: Trypanosomes of African fresh-water fish an addendum. Parasitology 51: 263.

BECKER C.D., OVERSTREET R.M. 1979: Haematozoa of marine fishes from the northern Gulf of Mexico. J. Fish Dis. 2: 469-479.

NEGM-ELDIN M.M. 1997: Trypanosoma mukasai (Hoare, $1932)$ in its biological vector Batracobdelloides tricarinata (Blanchard, 1897) and their life cycles. Dtsch. Tieraerztl. Wochenschr. 104: 215-219.

NEGM-ELDIN M.M. 1998: Further studies on Trypanosoma mukasai Hoare, 1932 and its biological vector Batracobdelloides tricarinata (Blanchard, 1897). Dtsch. Tieraerztl. Wochenschr. 105: 175-181.

PAPERNA I. 1996: Parasites, infections and diseases of fishes in Africa - an update. CIFA Tech. Pap. 31, pp. 1-220.
PIENAAR U.D.V. 1962: Haematology of Some South African Reptiles. Witwatersrand University Press, Johannesburg, 299 pp.

REED C.C., BASSON L., VAN AS L.L. 2002: Myxobolus species (Myxozoa), parasites of fishes in the Okavango River and Delta, Botswana, including descriptions of two new species. Folia Parasitol. 49: 81-88.

SKELTON P. 2000: A Complete Guide to the Freshwater Fishes of Southern Africa. Struik Publishers, Cape Town, $395 \mathrm{pp}$.

SMIT N.J., DAVIES A.J., VAN AS J.G. 2000: A trypanosome from the silver catfish (Schilbe intermedius) in the Okavango Delta, Botswana. Bull. Eur. Assoc. Fish Pathol. 20: 116-119.

SMIT N.J., VAN AS J.G., DAVIES A.J. 2003: Observations on Babesiosoma mariae (Apicomplexa: Dactylosomatidae) from the Okavango Delta, Botswana. Folia Parasitol. 50: 85-86.

Accepted 19 February 2004 